\title{
Social Disloyalty and Modesty in The Teachers' Career Development in The Digital Era
}

\author{
Harsono $^{1}$, Muhammad Yahya, ${ }^{2}$ Muhammad Fahmi Johan Syah ${ }^{3}$ \\ ${ }^{1}$ Universitas Muhammadiyah Surakarta, Indonesia $₫$ (e-mail) har152@ums.ac.id \\ ${ }^{2}$ Universitas Muhammadiyah Surakarta, Indonesia $₫$ (e-mail) my239@ums.ac.id \\ ${ }^{3}$ Universitas Muhammadiyah Surakarta, Indonesia $₫$ (e-mail) mfj120@ums.ac.id
}

\begin{abstract}
This study aims to describe the antagonistic behavior of teachers in the digital era. They have been bureaucratically polite by obeying the time and work schedule, but the atmosphere of the class is unfavorable even conflicted during the learning process. This is a qualitative research with ethnographic design conducted in Boyolali Regency, Central Java. The source persons were the perpetrators and academic rivals. The data analysis was done with a data analysis model in sites. This study finds out that politeness and social disaster is patterned, cultured, and at the same time they trigger the intrigue of family and society, correspondingly. The digital knowledge of teachers is fairly low and they tend to use it for unrelated professional development activities. The principal underestimates the conflict and does not perceive it as a threat for school bureaucracy. However, teacher's internal family issues are not part of the principal's professional concern.
\end{abstract}

Keywords: modesty, social disaster, and teachers' career development

\section{Introduction}

Education is affected by the digital growth. The aspects of learning process, evaluation, preparing prospective teachers, and enhancing teacher professionalism are gradually changed to be more digitally. Technology should help teachers to access new sources and manage their profession in any various circumstances (Ciolan, Petrescu, Radulescu, \& Bucur, 2014). In this era, professional learning network will support the professionalism of whole teachers (Trust, Krutka, \& Carpenter, 2016). The learning process tends to be online learning which is there is a possibility that a teacher has many students across the area. The teachers and the pupils use gadget to access the material and even teaching by using video conference.

In the normal situation in this digital era, teachers who are unable to perform their profession appropriately usually quit their jobs (Konig \& Lauermann, 2016; Kaja, Golonka \& Marek, 2015). Those who do not have professional competence relatively have insufficient professional knowledge, skills, confidence, and strong motivation on how to be a successful teacher (Konig \& Lauermann, 2016). Nevertheless, school is a complex entity thus teachers must carry out various tasks, which involve many and complicated technical and management aspects (Ikhsan \& Anisykulillah, 2010, 1).

Burnout significantly affects the performance of teachers (Shamsafrouz \& Branch, 2015). In this condition, when teachers get the feeling of high burnout, they will have lower performance. Teachers in rural areas may suffer dissatisfaction in their job, which leads to psychological illness (Dennis, 2008; Hakanen, Bakker, \& Schaufeli, 2006). The condition will decrease their performance. Some factors, such as job environment, administration task, academic task, promotion and evaluation from the supervisor and lack of research fund, will increase burnout among teachers (Karabiyik, Eker \& Anbar, 2008).

A study carried out in Kenya found the overload in number of students and tasks, working hour longer than 8-hours a day, work environment, social support and personality will increase burnout of teachers in rural areas (Salami, 2011; Sichambo \& Maragia, 2012). The complexity accompanying the performance of tasks may lead to physical fatigue and stress. Burnout is actually the ultimate 
condition of stress that represents in the form of physical fatigue, mental exhaustion, emotional fatigue, depersonalization, and low self-esteem as the consequence of long-term involvement in impersonal demanding situations (Rahman, 2007; Kristensen, Marianne, Villadsen \& Christensen, 2007). Burnout is also caused by the large number of students, noisy place, mischievous students, indiscipline, insensitive administration, rudeness and aggressiveness (Purba, Yulianto \& Widyanti, 2007: 82; Marin \& Campayo, 2010). It also relates to gender in which women have a higher tendency to burnout (Purvanova \& Muros, 2010). In fact, teachers suffering from burnout have a propensity to be disloyal in obeying social structure. However, cultural values are the guidelines for behavior that must be obeyed by the involved parties in the activity (Eric S, Linda Baier, Thomas R, \& Mark, 2007). Teachers who have conflict with colleagues or other school educational staffs, have an affair, divorce, or perform inappropriate activities will be rejected by the community.

Conflict, affair, and harshness can be perceived as an impolite act. Linguistic politeness or politeness in language is highly linked to the norm of a society (Sauri, 2003, 46). People with linguistic politeness are those who are capable of communicating, both verbal and written, without violating the prevailing social values. Sauri (2003) emphasized the cultural paradigm shift toward Western culture has brought numerous improper terms/speeches among students. Teachers must have a concern for the environment by neither littering nor destroying any plants (Rahmawati \& Suwanda, 2015).

Furthermore, teachers shall be role model for their students, including how to speak, dress up, act and behave, as well as to provide affection and encourage the students in performing their activities (Rahmadi, 2017). Yet in Indonesia, many students undergo behavior disorder and involvement in crime as indicated by 420 criminal cases in Lampung that were allegedly engaged by teenagers, including robbery, blackmail, brawl, drug use, rape even murder (Yanti, 2005). Recently, such phenomena are intensified as demonstrated by school violence where an art teacher of a senior high school in Sampang Madura died in the class after hit by student (Tribunnews.com, 1 February 2018) and a teacher was injured for being attacked by a student's guardian (Tribunnews.com, 6 October 2017).

Several teachers have recognized the dissemination of the concept of violence that indirectly spread to the school circumstance (Budoyo, Haryono \& Timur, 2018). Violence experienced by the students, including physical abuse such as being hit, kicked and slapped, result in pain or injury to students. Physical abuse or violence is accompanied by psychic violence such as insults, harassment, humiliation, and offensive words (Rionaldi, 2014). Such cases are increasingly vulnerable with lower frequency but higher intensity. The problems of aggressiveness and violence are fairly rampant, both performing by teachers to students and student to peers, as well as both physical and psychological violence (Maghfiroh \& Rahmawati, 2010).

Currently, the improvement of teacher activities related to their professional career development is very rapid. A number of literacy and seminar activities are organized by the community and government. At the same time, teachers who quit at a certain position in the long period are also higher.

\section{Methods}

This study is a qualitative research with an ethnographic design in which it studies the meaning of words, actions, and documents on an event or case (Harsono, 2016; Schensul, Schensul \& LeCompte, 1999; LeCompte \& Schensul, 1999). Ethnography investigates how an event occurs through a nonparticipatory observational approach (Gobo \& Molle, 2008: 6). Ethnography emphasizes on thought and findings (Brewer, 2005: 17). Information collected from the study are interpreted, contemplated and analyzed to build propositions and hypotheses as research findings. The subjects of the study were the teachers subjected to the topic of the study while the objects were the activities, behaviors, and relationships (Gobo \& Molle, 2008: 74). The subjects of the study or resource persons were 
perpetrators, rivals, and third party. These subjects became the consideration of the source of triangulation.

The research instrument is the researcher with the sensitivity to compare between the perpetrators' behavior with what they say in an ideal situation and their actions in a particular topic (Murchison, 2010: 13). Data were collected through in-depth interviews, observations, and documentation according to the theme of the research (LeCompte \& Schensul, 1999: 125; Sukoharsono, 2009). It becomes a consideration for the implementation of the triangulation method.

Data analysis was commenced from testing the validity of data using the triangulation method, followed by interpretation, sorting, and grouping of data based on the theme (LeCompte \& Schensul, 1999: 3). An analysis was done with data analysis model in the site (Harsono, 2016). Similar themes were used to construct the propositions and hypotheses of the research findings (Brewer, 2005: 107).

\section{Results and Discussion}

Boyolali Regency is situated in the slope of Mount Merapi and Mount Merbabu. In 2016, the population of this regency is 963,690 people, with density of 949 people per $\mathrm{km}^{2}$. The area is dominated by dry land, mixed gardens, and forests (BPS Kabupaten Boyolali). The number of primary schools, both public and private, is 802 schools. The number of junior secondary schools, both public and private, is 91 schools. The number of senior high schools, both public and private, is 48 schools. The number of vocational high schools, both public and private, is 33 schools. The number of schools indicates the complexity of school management, which is relatively higher.

Table 1. Number of schools, students and teachers in 2013

\begin{tabular}{llcccc}
\hline No & \multicolumn{1}{c}{ School stage } & $\begin{array}{c}\text { Number of } \\
\text { school }\end{array}$ & $\begin{array}{c}\text { Number of } \\
\text { students }\end{array}$ & $\begin{array}{c}\text { Number of } \\
\text { teachers }\end{array}$ & $\begin{array}{c}\text { Teacher: } \\
\text { student ratio }\end{array}$ \\
\hline 1 & Kindergarten & 537 & 17,750 & 1,468 & 12 \\
\hline 2 & Primary School & 603 & 74,104 & 5,864 & 13 \\
\hline 3 & Junior Secondary School & 91 & 34,190 & 2,506 & 14 \\
\hline 4 & Senior Secondary School & 74 & 28,246 & 2,457 & 11 \\
\hline
\end{tabular}

Source: BPS Kabupaten Boyolali.

One teacher for 11 to 14 students is assumed as the ideal ratio based on the Government Regulation No. 74 of 2008, which stipulates the range of 12-20 students for a teacher for the level of kindergarten to senior secondary school. Meanwhile, in ASIA, a teacher has to handle at least 24 students (ACDP, May 13, 2015). By the determination of the number, it is expected that the relationship between teachers and students as well as the relationship among teachers is constructive.

In the meantime, the Government Regulation No. 19 of 2017 as the amendment of the Government Regulation No. 74 of 2008 stipulates the workload of teacher is 40 teaching hours per week or 24 hours per subject. In terms of assignment of 24 teaching hours, a teacher has to teach approximately 12 teaching hours while 40 teaching hours means the teacher is on duty from 7:00 a.m. to 3.00 p.m. every per day. Teachers leave home at 6:00 a.m. and return home at 4:00 p.m. Therefore, the average hour for teachers staying at school is 8-9 hours.

Incentive provided for certified educators with 24 teaching hours or 40 hours of duty in a week is expected to improve the independence of teachers in carrying out their activities. By earning well, teachers can focus on their main duty without seeking other activities for additional income. The phenomena of teachers who also become motorcycle taxi driver or similar activities that disrupt their main duty. The needs of teachers and their families can be afforded by their salary, additional income, and teacher certification program. However, several female teachers perform like a movie star with excessive makeup, clothes, accessories, bag, mobile phones, shoes and perfume. In some cases, they show up in luxury like in a pageant. 
A teacher had a relationship with a district official and frequently took a walk at malls just to exhibit her life style. Once or twice, she was tempted to buy accessories. Furthermore, she desired for new dresses with a fashionable design, branded handbags, latest mobile phones, stylish shoes, and so on. As the new way of life began, it seemed reluctant to return to such a simple life. She left her husband and family to be with a wealthy man in an unregistered marriage (nikah siri). After the husband divorced his official wife, she replaced the position and moved to his house.

When the husband entered his retirement age, his status and position vanished. It brought consequences, including limited income, and the wind began to change its direction. The teacher approached another man who definitely wealthier. Deliberately or not, the third family was targeted. After the first was abandoned, the second was gradually left behind, and the third was initiated.

One of prior studies found that the trust for other parties is vital. It includes trust on companions and friends and affairs with another's spouse, in which consequently, things that should be blamed, the truth is in doubt. Therefore, the mutual feeling is more concerned than the social order that has lasted for ages. Since the truth is situated in friendship itself. A study that found a determined moral foundation on the students' perspective, which focused on trust and friendship, hence inappropriate behavior is accepted while the behavior that is actually refused by the society is considered dubious (Ashworth, Bannister \& Thorne, 2006).

Generally, teachers who perform improper activities tend to cover their behaviors to people (except their close friends) with harsh and very responsive behavior. In the USA, research on such a behavior is described as reactive, proactive, and aggressive acts that serve as an instrument to conceal their antisocial behavior (Fontaine, 2006). They continued to believe in themselves, by giving up their previous relationship through a divorce. The secretive romance was continued as an affair and finally in a formal marriage. Perhaps, love is not the real reason since the lust to have a lavish appearance is more dominant. Respectable appearance is gained by having better consumption than others.

Another behavior is the penchant for shopping on goods that have high prestige, such as branded clothes, bags, and shoes. They also have a hobby to browse the latest gadget at booths and malls. Nevertheless, the results of other studies also demonstrated different findings. Despite showing the problems endured due to the class shift, the studies carried out by Wideen, Smith and Moon (1998) as well as Lori, David E, Jenifer, Glenda, \& Andrew (2013) showed that class shift potentially leads to contentment and motivation.

Officials queue to be placed while displacements may trigger other problems. The pattern is found in studies carried out in Bengkulu and the United States. In Belgium, conflicts are mainly related to gender, while in Indonesia, conflict arises because of its unique individual characteristics. In Indonesia, conflicts of teacher are confidential, while in Australia, the conflict is not secret for students as reported by Brown, Oliver, Hodgson, Palmer, \& Watts (2008).

\section{Conclusions}

This study describes the behavior of teachers in the digital era in which gender affects the life style as indicated by the preferences of consumption, dress up, accessories, gadget, as well as the habit for shopping, recreation, traveling and culinary. In this case, the behavior is uncontrollable. To attain their desires, they are can sacrifice their marriage and family. Such a way of life is in line with the demands for technological demands. The school does not support sufficient to address teacher's professionalism in the digital era, moreover exclusive life style for them. Nevertheless, they refuse to open up their secret. They know well that the act is improper, yet they are powerless to resist it. Consequently, they cover it with sensitive, irritable, reactive, and aggressive behavior to anyone who bothers them. 


\section{References}

Ashworth, P., Bannister, P. \& Thorne, P. (2006). Guilty in whose eyes? University students' perceptions of cheating and plagiarism in academic work and assessment. Studies in Higher Education, 22(2), 187-203.

Brewer, J. D. (2005). Ethnography. Philadelphia: Open University Press.

Budoyo, S., Haryono, \& Timur, W. (2017). Persepsi Guru Gugus Wijayakusuma UPTD Pendidikan Kecamatan Pedurungan terhadap Perlindungan Profesi Guru. Semarang: Fakultas Hukum Universitas PGRI Semarang.

Brown, J. S., Oliver, R., Hodgson, D., Palmer, M. \& Watts, L. (2008). Good teachers/bad teachers: How rural adolescent students' views of teachers impact on their school experiences. Australian Journal of Teacher Education, 33(6).

Ciolan, L., Petrescu, A., Radulescu, C., \& Bucur, C. (2014). Training teachers to use digital resources for the knowledge society. Procedia - Social and Behavioral Sciences, 128, 415-419. Retrieved from http://doi.org/10.1016/j.sbspro.2014.03.180

Dom, L. \& Verchoeven, J. C. (2007). Partnership and Conflict between parents and schools: How are schools reacting to the new participation law in Flanders (Belgium)? Journal of Education Policy, 21(5).

Eckmen, E. W. (2004). Similarities and differences in role conflict, role commitment, and job satisfaction for female and male high school principals. Educational Administration Quarterly, 1.

Eric S. W., Manwell L. B., Konrad, T. R. \& Linzer, M. (2007). The Relation of Organizational Culture, Stress, Satisfaction, and Burnout with physician-reported error and suboptimal patient care: Results from the MEMO study. Health Care Management Review, 32(3), 203-212.

Everston, C. M. \& Smithey, M. W. (2010). Mentoring effects on protégés classroom practice: An experimental field study. The Journal of Educational Research, 93(5), 294-304.

Fontaine, R. G. (2006). Evaluative behavioral judgments and instrumental antisocial behaviors in children and adolescent. Clinical Psychology Review, 26(8), 956-967.

Fuller, B. \& Clarke, P. (1994). Raising school effects while ignoring culture? Local conditions and the influence of classroom tools, rules, and pedagogy. Review of Educational Research, 1.

Gobo, G. \& Molle, A. (2008). Doing Ethnography. 1st Ed. Melbourne: SAGE Publication Inc. ISBN: 978-14129-6226-1.

Harsono. (2007). Meningkatkan prestasi belajar melalui kelompok belajar informal: Studi kelompok informal siswa SMA di Boyolali, Jawa Tengah, Indonesia. Varia Pendidikan. 19(2).

Harsono. (2016). Ethnografi Pendidikan: Suatu Desain Penelitian Kualitatif. Surakarta: Jasmine. ISBN: 978602-6871-12-1.

Hoglund, W. L. \& Leadbeater, B. J. (2004). The effect of family, school, and classroom ecologies on changes in children's social competence and emotional and behavior problems in first grade. American Psychological Association, 40(4), 533-544.

Ikhsan, S. \& Anisykurillah, I. (2010). Penerapan manajemen berbasis sekolah SMK Negeri dan SMK swasta se-Keresidenan Semarang. Jurnal Pendidikan Ekonomi Dinamika Pendidikan, (5)1.

Kaja, J. M., Golonka, K. \& Marek, T. (2015). Job burnout and engagement among teachers-worklife areas and personality traits as predators of relationships with work. International Journal of Occupational Medicine and Environmental Health, 1, 102-119.

Kristensen, T. S., Villadsen, B. M., Villadsen, E. \& Christensen, K. B. (2007). The Copenhagen Burnout Inventory: A new tool for the assessment of burnout. Journal Work \& Stress: An International Journal of Work, Health \& Organization, 9(3), 192-207.

Lauermann, F. \& Konig, J. (2016). Teacher professional competence and wellbeing: Understanding the links between general pedagogical knowledge, self-efficacy and burnout. Learning and Instruction, (45), 9-18.

LeCompte, M. D. \& Schensul, J. J. (1999). Designing Conducting Ethnographic Research. New York: Altamira Press. 
Lori, B., Pritchard, D. E., Deboer, J., Stump, G. \& Ho, A. H. (2013). Studying learning in the worldwide classroom: Research into edX's Mooc. Research \& Practice in Assessment, Lynchburg, 8, 13.

Maghfiroh, U. \& Rahmawati, M. A. (2010). Hubungan antara iklim sekolah dengan kecenderungan perilaku bullying. Jurnal Universitas Islam Indonesia.

Manap. (2011). Proyeksi Kebutuhan Pengangkatan Kepala Sekolah di Kota Bengkulu tahun 2012-2013. Prodi Magister Manajemen Pendidikan. Universitas Bengkulu, Bengkulu.

Murchison, J. M. (2010). Ethnography Essentials: Designing, Conducting, and Presenting your Research. $1^{\text {st }}$ Ed. Hoboken: JOSSEY-BASS, John Wiley \& Sons.

Marin, J. M. \& Campayo, J. G. (2010). A Newer and Broader Definition of Burnout: Validation of the Burnout Clinical Subtype Questionnaire (BSCQ-36). Retrieved from www.biomedcentral.com/ $\underline{1471-2458 / 10 / 302 .}$

Prasojo, B. (2012). Pengaruh Pemberian kompensasi nonfinansial terhadap kinerja guru SMP Negeri se Kecamatan Bantul. Hanata Widya, 2(1). Yogyakarta: FIP UNY.

Purba, J., Yulianto, A. \& Widyanti, E. (2007). Pengaruh dukungan sosial terhadap burnout pada guru. Jurnal Psikologi. 5(1), 77-87.

Purvanova, R. K. \& Muros, J. P. (2010). Gender differences in burnout: A meta-analysis. Journal of Vocational behavior, 77(2), 168-185.

Rahmadi, D. (2017). Penanaman karakter sopan santun oleh guru PKN di SMAN 1 Sukadana Kabupaten Kayong Utara. Jurnal Pendidikan Kewarganegaraan. 1(2), 181-190.

Rahman, U. (2007). Mengenal Burnout pada Guru. Lentera Pendidikan, X(2), 216-227.

Rahmawati \& Suwanda. (2015). Kajian Moral dan Kewarganegaraan, 1(3), 71-88.

Rionaldi, A. (2014). Tinjauan Yuridis terhadap Kekerasan yang dilakukan Oknum Guru terhadap Murid di Sekolah.Yogyakarta: Fakultas Hukum Universitas Atmajaya. Retrieved from http://e-journal uajv.ac.id/id/eprint/6029.

Sukoharsono. (2009). Refleksi ethnografi kritis: Pilihan lain teknik riset akuntansi. Accounting Research Training Series 5-Kritis PDIA-PMA JAFEB Universitas Brawijaya, 22-23 Januari 2014. Retrieved from www.multiparadigma.lecture.ub.ac.id.

Sauri, S. (2003). Pengembangan strategi pendidikan berbahasa santun di sekolah. Mimbar Pendidikan. $1(\mathrm{XXII})$.

Schensul, S. L. Schensul, J. J. \& LeCompte, M. D. (1999). Essential Ethnographic Methods: Observations, Interviews, and Questionnaires. New York: Altamira Press.

Sujarwo, I. (2013). Upaya meningkatkan kedisiplinan guru dalam kehadiran mengajar di kelas melalui penerapan reward dan punishment di SMAN I Warureja Kabupaten Tegal 2012/2013. JP Kreatif, 1(1).

Trust, T., Krutka, D. G., \& Carpenter, J. P. (2016). Together we are better: Professional learning networks for teachers. Computers and Education, 102, 15-34. Retrieved from http://doi.org/10. 1016/j.compedu.2016.06.007

Wideen, M., Mayer, S. J., \& Moon, B. (1998). A critical analysis of the research on learning to teach: Making the case for an ecological perspective on inquiry. Review of Educational Research.

Yanti, D. (2005). Ketrampilan sosial pada anak menengah akhir yang mengalami gangguan perilaku. e-USU Repository. Universitas Sumatera Utara. 